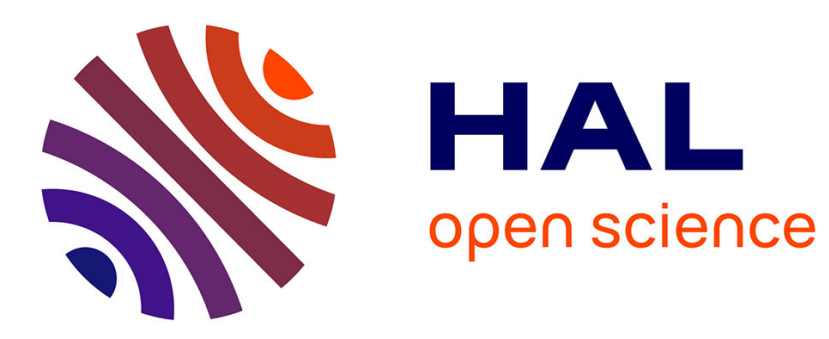

\title{
Gene Electrotransfer in 3D Reconstructed Human Dermal Tissue
}

\author{
Moinecha Madi, Marie-Pierre Rols, Laure Gibot
}

\section{To cite this version:}

Moinecha Madi, Marie-Pierre Rols, Laure Gibot. Gene Electrotransfer in 3D Reconstructed Human Dermal Tissue. Current Gene Therapy, 2016, 16 (2), pp.75-82. $10.2174 / 1566523216666160331125052$. hal-03079981

\section{HAL Id: hal-03079981 https://hal.science/hal-03079981}

Submitted on 17 Dec 2020

HAL is a multi-disciplinary open access archive for the deposit and dissemination of scientific research documents, whether they are published or not. The documents may come from teaching and research institutions in France or abroad, or from public or private research centers.
L'archive ouverte pluridisciplinaire HAL, est destinée au dépôt et à la diffusion de documents scientifiques de niveau recherche, publiés ou non, émanant des établissements d'enseignement et de recherche français ou étrangers, des laboratoires publics ou privés. 


\title{
Gene Electrotransfer in 3D Reconstructed Human Dermal Tissue
}

\author{
Moinecha Madi ${ }^{\mathrm{a}, \mathrm{b}}$, Marie-Pierre Rols ${ }^{\mathrm{a}, \mathrm{b}^{*}}$, Laure Gibot $^{\mathrm{a}, \mathrm{b}^{*}}$ \\ ${ }^{a}$ IPBS-CNRS, 205 route de Narbonne, 31077 Toulouse, France; ${ }^{b}$ Université de Toulouse, UPS, 31077 \\ Toulouse, France
}

\begin{abstract}
Gene electrotransfer into the skin is of particular interest for the development of medical applications including DNA vaccination, cancer treatment, wound healing or treatment of local skin disorders. However, such clinical applications are currently limited due to poor understanding of the mechanisms governing DNA electrotransfer within human tissue. Nowadays, most studies are carried out in rodent models but rodent skin varies from human skin in terms of cell composition and architecture. We used a tissue-engineering approach to study gene electrotransfer mechanisms in a human tissue context. Primary human dermal fibroblasts were cultured according to the self-assembly method to produce $3 \mathrm{D}$ reconstructed human dermal tissue. In this study, we showed that cells of the reconstructed cutaneous tissue were efficiently electropermeabilized by applying millisecond electric pulses, without affecting their viability. A reporter gene was successfully electrotransferred into this human tissue and gene expression was detected for up to $48 \mathrm{~h}$. Interestingly, the transfected cells were solely located on the upper surface of the tissue, where they were in close contact with plasmid DNA solution. Furthermore, we report evidences that electrotransfection success depends on plasmid mobility within tissue-rich in collagens, but not on cell proliferation status. In conclusion, in addition to proposing a reliable alternative to animal experiments, tissue engineering produces valid biological tool for the in vitro study of gene electrotransfer mechanisms in human tissue.
\end{abstract}

Keywords: Delivery, plasmid DNA, electroporation, extracellular matrix, gene therapy, skin, tissue engineering

\section{INTRODUCTION}

Since few decades, a physical method named electroporation has been developed to locally deliver therapeutic drugs (cytotoxic molecules and nucleic acids) to a large range of targeted tissues [1-5]. This promising method is currently applied in human clinics. The major fields of application of DNA electrotransfer are vaccination and gene therapy in oncology [6-8]. Clinical applications have already began in veterinary and human oncology [911]. Hopeful results have been obtained with the first published phase-I trial on interleukin-12 electroporation, conducted in a cohort of patients with metastatic melanomas [12].

However, while gene electrotransfer is highly efficient in a large panel of cell lines in vitro, gene expression is usually less efficient in vivo in some tissues such as tumors and the skin $[7,13]$. Although the first study on DNA electrotransfer was initiated more than 30 years ago [14], underlying mechanisms are not yet fully understood, in particular in in vivo situations [15]. It is therefore still mandatory, for further developing the method in clinics, to increase our knowledge of the process.

The skin is an appealing tissue target for gene electrotherapy because of its large surface area, its accessibility and its immunological properties with antigen presenting cells present both in the epidermis and in the dermis [16]. Gene electrotransfer to muscle tissue is highly effective and leads to long-term transgene expression $[17,18]$. With some plasmids and under optimized delivery conditions, it could achieve higher expression than in skin [19]. Nevertheless, high and/or long- term transfection are not always required [20]. For example, in wound healing, there is no need for therapeutic growth factor transgene expression when the wound has closed [21,22]. Similarly, DNA vaccination does not require a continuous production of antigens once the immune system has responded to the vaccine $[4,23]$. Donate and collaborators gave evidence that vaccine to the skin is as, if not more, efficient than delivery to muscle [24]. Gene electrotransfer to the skin can be as efficient as muscle as reported by Heller et al showing over $30 \%$ efficiency delivering to the skin [25].

Skin consists of distinct cell types, mainly keratinocytes, melanocytes, Langerhans cells, fibroblasts and endothelial cells. This diversity of cell types can differently respond to gene transfection depending on the plasmid construction (i.e., tissue-specific promoters), on the electrical parameters and/or on the type of electrodes used.

\footnotetext{
*Address correspondence to this author at IPBS-CNRS, 205 route de Narbonne, 31077 Toulouse, France; Tel/Fax: +33-561-175-827, +33-561-
} 175-994; E-mails: gibot@ipbs.fr; rols@ipbs.fr 
In order to understand the role of each parameter of the experimental setup on the distinct cell types present within the skin during the gene electrotransfer process, relevant biological models of human skin tissue have to be developed.

Using the tissue engineering self-assembly approach [26], we produced reconstructed human dermal tissue, devoid of any exogenous material, and rich in native extracellular matrix [27,28]. In this context, primary human dermal fibroblasts reproduce a native environment, by secreting and organizing a 3D extracellular matrix dense in collagens. These abundant collagen fibrils were clearly detected by second harmonic generation (SHG) [29]. In a previous study, we showed that this tissue-engineered model is efficiently electropermeabilized with millisecond electric pulses [29]. Thus, we propose here to further examine gene electrotransfer mechanisms in vitro in human tissue by using this relevant and useful biological model.

\section{MATERIALS AND METHODS}

Cell culture. Primary human dermal fibroblasts were extracted from human child foreskin after posthectomy as previously described [27]. Primary cells were grown at $37^{\circ} \mathrm{C}$ in Dulbecco's Modified Eagles Medium (Gibco-Invitrogen, Carlsbad, USA) supplemented with $10 \%$ fetal calf serum, $100 \mathrm{U} / \mathrm{ml}$ penicillin and $100 \mu \mathrm{g} / \mathrm{ml}$ streptomycin.

Reconstruction of human 3D dermal tissue. Human dermal substitutes, devoid of any exogenous material, were reconstructed in vitro according to the self-assembly approach. In a few words, primary human dermal fibroblasts were grown for three weeks in cell culture medium supplemented with $50 \mu \mathrm{g} / \mathrm{mL}$ of ascorbic acid (SigmaAldrich) as already published [28,29]. After three weeks, enough extracellular matrix was secreted to produce a cell sheet that is easy to manipulate. Since the cells are primary dermal fibroblasts, extracellular matrix is comparable to human dermis.

Collagen detection by second harmonic generation (SHG). Stacks of $425 \times 425 \times 60 \mu \mathrm{m}$ were acquired using a 7MP multiphoton microscope (Carl Zeiss, Jena, Germany) coupled to a Ti-Sapphire laser, Chameleon Ultra 2 (Coherent Inc) settled to $800 \mathrm{~nm}$. Organized fibrillar collagens were detected by second harmonic generation at a wavelength of $400 \mathrm{~nm}$. Imaris software (Bitplane AG) was used to analyzed the acquired $3 \mathrm{D}$ images.

Electropermeabilization and gene electrotransfer in 3D human dermal tissue. Two flat parallel stainless steel electrodes were placed on the top of a cell sheet and immersed in pulsing buffer (10 mM K2HPO4/ KH2PO4 buffer, $1 \mathrm{mM} \mathrm{MgCl} 2,250 \mathrm{mM}$ sucrose, $\mathrm{pH}$ 7.4) containing or not $100 \mu \mathrm{M}$ propidium iodide (PI) (Sigma-Aldrich) or $2 \mu \mathrm{g}$ of $4.7 \mathrm{~kb}$ pEGFP-C1 DNA plasmid (Clontech, \#6084-1). Electropulsation was performed with an ELECTRO cell S20 generator ( $\beta$ Tech, Toulouse, France) which delivered squarewave electric pulses. The electrical conditions were the following: 8 pulses lasting $5 \mathrm{~ms}$ at a frequency of $1 \mathrm{~Hz}$ applied from 0 to $800 \mathrm{~V} / \mathrm{cm}$ at room temperature.

Electropermeabilization detection and quantification. Cell membrane permeabilization was analyzed on living tissues by multiphoton microscopy. Electropermeabilization efficiency was investigated by adding PI to the pulsation buffer during electric field application. IMARIS software was used to draw an isosurface and to isolate the electropermeabilized cells (i.e. cells in which PI was present).

Cell viability. Tissue viability was determined by adding PI $24 \mathrm{~h}$ after application of the electric field. Viability was also quantified using PrestoBlue assay (Invitrogen) according the manufacturer's protocol. Briefly, 24h after electric field application, the cell sheet was incubated for $30 \mathrm{~min}$ at $37^{\circ} \mathrm{C}$ in a PrestoBlue solution. Absorbance (excitation $570 \mathrm{~nm}$, emission $600 \mathrm{~nm}$ ) was then read using a plate reader (Clariostar, BMG). Controls, named "Dead" were cell sheets subjected to 3 freeze/thaw cycles).

Reporter gene electrotransfer efficiency. 3D stacks showing both SHG and efficiently electrotransfected GFPpositive cells were acquired using a multiphoton laser scanning microscope. Pictures were analysed with IMARIS software to show both top and side views of the cell sheet. Image J software (NIH, Bethesda, USA) was used to quantify the GFP-positive areas within total pictures $(425 \times 425 \mu \mathrm{m})$.

Cell proliferation within dermal tissue. Cell proliferation was assessed with Click-it® EdU Alexa Fluor ${ }^{\circledR}$ imaging kit (Molecular Probes). In a few words, cell sheet was

incubated for $24 \mathrm{~h}$ with $10 \mu \mathrm{M}$ EdU before being processed according to the manufacturer's recommendations. Reconstructed dermal tissues were observed with a 7MP multiphoton laser scanning microscope.

DNA staining and gene electrotransfer. pEGFP-C1 plasmid was stoichiometrically labelled with TOTO-1 (Molecular Probes), a DNA intercalating dye as previously described [30]. The plasmid was stained with $2.3 \times 10-4 \mathrm{M}$ dye at a DNA concentration of $1 \mu \mathrm{g} / \mu \mathrm{l}$ for $60 \mathrm{~min}$ on ice. Cell sheet was incubated in labeled plasmid-containing pulsation buffer and exposed to 8 pulses each lasting $5 \mathrm{~ms}$ at a frequency of $1 \mathrm{~Hz}$ at $800 \mathrm{~V} / \mathrm{cm}$ at room temperature. Cell sheets were observed 1 minute after the pulses with the $7 \mathrm{MP}$ multiphoton laser scanning microscope.

Statistical analyses. Statistical significance in cell viability after different electrical treatments was determined using 1way ANOVA with a Dunnett's post-test. Statistical analyses used GraphPad Prism software, version 4.02 (GraphPad Software, San Diego, USA). All plotted data were expressed as means \pm SEM.

\section{RESULTS AND DISCUSSION}

The aim of our study was to examine the relevance of reconstructed human dermal tissue as a model to address 
gene electrotransfer processes. To do so, we used standard electrical parameters for gene electrotransfer (i.e, 8 pulses lasting $5 \mathrm{~ms}$ at $1 \mathrm{~Hz}$ frequency with field intensities from $0 \mathrm{~V} / \mathrm{cm}$ to $800 \mathrm{~V} / \mathrm{cm})$. Multiphoton imaging allowed visualization of membrane permeabilization, gene transfer and expression at the single cell level within tissue, on fresh human models. Cell uptake of propidium iodide was used to detect membrane permeabilization. A plasmid carrying the Green Fluorescent Protein gene allowed detection of gene transfer and expression. This methodology addresses the following issues: (i) Can the cells within reconstructed dermal tissue be efficiently electropermeabilized and transfected? (ii) Does transfection affect cell viability? (iii) Does the location of the cells within the tissue and their proliferative status affect the process?

Cells within reconstructed human dermal tissue are efficiently electropermeabilized by millisecond electric pulses. Electropermeabilization was assessed by adding propidium iodide during electric field application. Images obtained by microscopy were analyzed by IMARIS software which allows cell sheets to be visualized both from top and side views (Fig. 1). In the control condition $(0 \mathrm{~V} / \mathrm{cm})$, a few permeable cells that correspond to dead cells were observed in the cell sheet. Indeed, cell renewal takes place in the reconstructed human dermal tissue model, and dead cells are entrapped within the extracellular matrix. By applying the electric pulses and increasing the electric field intensity, cells located both on the surface and in depth were efficiently and homogeneously electropermeabilized. Thus, the whole cells embedded within the tissue model can be electropermeabilized. We then checked whether membrane permeabilization was transient or not. Irreversible electroporation (IRE) offers great promise in interventional oncology with thermal or non-thermal tumor ablation $[4,31]$. However, IRE has to be avoided in gene therapy since it is not compatible with gene expression.

Cell viability within tissue is preserved after application of millisecond electric pulses. Membrane resealing occurs in about 20 minutes after application of millisecond pulses [32,33]. Thus, when added $24 \mathrm{~h}$ after the electric pulses, PI only enters into irreversibly permeabilized cells i.e. dead cells. Control tissues revealed only a few positive cells while "dead" tissue was highly fluorescent. Images showed no significant increase in the number of dead cells after applying the electric field up to $600 \mathrm{~V} / \mathrm{cm}$ (Fig. 2A). A resazurin-based functional test involving viable cell metabolic activity (Fig. 2B), was used to quantify tissue viability and showed no statistical difference between control cells $(0 \mathrm{~V} / \mathrm{cm})$ and cells pulsed up to $600 \mathrm{~V} / \mathrm{cm}$. A statistically non-significant decrease was observed at $800 \mathrm{~V} / \mathrm{cm}$, as confirmed by PI-positive cells increase on fluorescent pictures. At $800 \mathrm{~V} / \mathrm{cm}$, side views indicated that dead cells were situated on the top of the cell sheet (data not shown). Previous histological analyses showed that several thousand cells are embedded in multiple layers within the 50 $\mu \mathrm{m}$ thick sheet [29]. Thus, even though some cells appeared positive to PI at $800 \mathrm{~V} / \mathrm{cm}$, their number was not significant.
Accordingly, millisecond electric pulses up to $800 \mathrm{~V} / \mathrm{cm}$ did not significantly affect cell viability within the dermal tissue.

Gene electrotransfer is spatially and temporally limited within the tissue. GFP reporter gene plasmid was electrotransferred within 3D reconstructed dermal tissue (Fig. 3). No transfected cells were detected when no electric field was applied $(0 \mathrm{~V} / \mathrm{cm})$ or when no plasmid DNA was added (data not shown). GFP expression was observed $6 \mathrm{~h}$ after gene electrotransfer and lasted up to $72 \mathrm{~h}$ (data not shown). Electrotransfection was observed for electric field intensities above $200 \mathrm{~V} / \mathrm{cm}$, i.e. under electric field conditions leading to cell electropermeabilization. GFPexpressing cells increased with the electric field intensity. Cross-sectional views showed that only cells located at the top of the cell sheet were efficiently transfected (Fig. 3A), whatever the electric field intensity. This could be due to the fact that only the top of the sheet was in contact with the plasmids during application of the electric field. Quantification of GFP-positive area $24 \mathrm{~h}$ and $48 \mathrm{~h}$ after gene electrotransfer revealed that the most efficient electric field intensity was $800 \mathrm{~V} / \mathrm{cm}$, leading to a $8 \%$ rate of transfection (Fig. 3B). This percentage is quite low compared to in vivo studies achieving 30\% efficiency delivery to the skin [25]. Further optimization of both electrodes geometry and placement could improve electric field distribution and increase plasmid mobility within our tissue model, leading to a better gene electrotransfer efficiency.

Reporter gene expression depends on plasmid mobility within the tissue but not on cell proliferation status. A hypothesis to explain why transfected cells where solely located at the tissue surface is that only these cells are proliferative. Proliferative cells are usually more efficiently electrotransfected because, as previously reported [34], the disintegration of the nuclear membrane during mitosis helps the direct access of DNA plasmid to the nucleus, enhancing gene expression. In order to characterize cell proliferation within our 3D model, we aimed to visualize cells engaged in S-phase replication [35]. A nucleoside analog of thymidine was added to the culture medium. Proliferative cells were homogenously distributed through the 3 dimensions within the reconstructed dermal tissue (Fig. 4A). This constant cell renewal cannot explain the localization of the transfected cells but could explain why transgene expression lasted for less than $72 \mathrm{~h}$.

We then aimed to determine if the accessibility of plasmid DNA to cells could explain why only cells in the upper part of the dermal tissue were transfected. To do so, cells were pulsed in the presence of a fluorescently labeled-plasmid DNA that allowed its 3D distribution within dermal tissue to be visualized (Fig. 4B). Under electrical parameters that induce efficient cell permeabilization and transfection (i.e $800 \mathrm{~V} / \mathrm{cm}$ ), plasmid DNA was showed to interact with the cells. Interestingly, this interaction was limited to the cell side facing the cathode as previously described on cells grown in monolayers and in suspension [30]. Thus, for the first time we were able to observe DNA-membrane 
interactions in a healthy tissue. Interestingly, by DNA spot patterns we were able to recognize fibroblast typical morphology. Indeed, these stromal cells are elongated cells growing oriented in parallel. Analysis of tissue crosssectional views revealed that fluorescent plasmid DNA was confined to the tissue surface. It has been reported that DNA plasmid electrophoretic transport is inversely correlated with the amount of collagen in tumor tissue [36]. Thus, tumors containing only some proteoglycans and collagens were found to be more efficiently electrotransfected in vivo than solid tumors with a rich extracellular matrix [37,38]. Collagen content modulates tumor tissue resistance to macromolecule diffusion by linking and stabilizing glycosaminoglycans [39]. ]. Since the reconstructed human dermal tissue is highly rich in collagens [29], it seems that this observation is also correct for solid healthy tissue.

We are now optimizing the electrical parameters to improve gene electrotransfer efficiency in a healthy tissue context. Indeed, some authors previously showed that an association of high voltage with low voltage pulses enhanced gene expression in skin [7,40-42]. Additionally, skin is a complex tissue composed of distinct cell types. Theoretically cell types with different morphological characteristics can be targeted and transfected by specific electrical parameters [32]. Thus, we plan to refine our skin tissue-engineered model by adding an epidermis compartment as previously described $[27,28]$ in order to study cell targeting. Finally, we would like to investigate the role of plasmid construction on gene electrotransfer efficiency in skin. Indeed, tissue-specific promoters lead to smaller transfection rates but specific cells can be better targeted $[43,44]$.

\section{CONCLUSION}

Reconstructed human dermal tissue appears to be a relevant tool to mimic and assess gene electrotransfer in human skin. Using this model, we will gain a better comprehension of the mechanisms involved in gene electrotransfer and its limits in tissues and propose strategies to improve its efficiency, while maintaining its safety, or to specifically target a particular cutaneous cell type.

\section{CONFLICT OF INTEREST}

Authors declare they have no competing financial interests. This work was supported by the Centre National de la Recherche Scientifique (CNRS) (MPR), the Agence Nationale de la Recherche (ANR) (MPR and LG), Projet PIERGEN ANR-12-ASTR-0039, and Mayotte department (MM).

\section{ACKNOWLEDGEMENTS}

The Research was conducted in the scope of the EBAM European Associated Laboratory (LEA) and is a result of networking efforts within COST TD1104 action.
Microscopy experiments were carried out at the Plateforme Genotoul Toulouse RIO Imaging. The authors would like to gratefully acknowledge Elisabeth Bellard (IPBS) for her technical assistance in imaging analysis and Peter Winterton, a native English scientist, for his careful proofreading of this manuscript.

\section{REFERENCES}

[1]. Gothelf A, Mir LM, Gehl J. Electrochemotherapy: results of cancer treatment using enhanced delivery of bleomycin by electroporation. Cancer Treat Rev 2003 Oct;29(5):371-87.

[2]. Rols MP. Gene transfer by electrical fields. Curr Gene Ther 2010 Aug;10(4):255.

[3]. Andre FM, Mir LM. Nucleic acids electrotransfer in vivo: mechanisms and practical aspects. Curr Gene Ther 2010 Aug;10(4):267-80.

[4]. Yarmush ML, Golberg A, Sersa G, et al. Electroporation-based technologies for medicine: principles, applications, and challenges. Annu Rev Biomed Eng 2014 Jul 11;16:295-320.

[5]. Mir LM, Bureau MF, Gehl J, et al. High-efficiency gene transfer into skeletal muscle mediated by electric pulses. Proc Natl Acad Sci U S A 1999 Apr 13;96(8):4262-7. [6]. Sersa G, Teissie J, Cemazar M, et al. Electrochemotherapy of tumors as in situ vaccination boosted by immunogene electrotransfer. Cancer Immunol Immunother 2015 Oct;64(10):1315-27.

[7]. Vandermeulen G, Staes E, Vanderhaeghen ML, et al. Optimisation of intradermal DNA electrotransfer for immunisation. J Control Release 2007 Dec 4;124(1-2):81-7.

[8]. Vandermeulen G, Vanvarenberg K, De Beuckelaer A, et al. The site of administration influences both the type and the magnitude of the immune response induced by DNA vaccine electroporation. Vaccine 2015 Jun 22;33(28):317985.

[9]. Cemazar M, Jarm T, Sersa G. Cancer electrogene therapy with interleukin-12. Curr Gene Ther 2010 Aug;10(4):300-11.

[10]. Heller LC, Heller R. Electroporation gene therapy preclinical and clinical trials for melanoma. Curr Gene Ther 2010 Aug;10(4):312-7.

[11]. Escoffre JM, Rols MP. Electrochemotherapy: progress and prospects. Curr Pharm Des 2012;18(23):340615.

[12]. Daud AI, DeConti RC, Andrews S, et al. Phase I trial of interleukin-12 plasmid electroporation in patients with metastatic melanoma. J Clin Oncol 2008 Dec 20;26(36):5896-903.

[13]. Rols MP, Delteil C, Golzio M, et al. In vivo electrically mediated protein and gene transfer in murine melanoma. Nature Biotechnology 1998 Feb;16(2):168-71.

[14]. Neumann E, Schaefer-Ridder M, Wang Y, et al. Gene transfer into mouse lyoma cells by electroporation in high electric fields. EMBO J 1982;1(7):841-5.

[15]. Escoffre JM, Portet T, Wasungu L, et al. What is (still not) known of the mechanism by which electroporation 
mediates gene transfer and expression in cells and tissues. Mol Biotechnol 2009 Mar;41(3):286-95.

[16]. Rochard A, Scherman D, Bigey P. Genetic immunization with plasmid DNA mediated by electrotransfer. Hum Gene Ther 2011 Jul;22(7):789-98.

[17]. Mir LM, Bureau MF, Rangara R, et al. Long-term, high level in vivo gene expression after electric pulsemediated gene transfer into skeletal muscle. C R Acad Sci III 1998 Nov;321(11):893-9.

[18]. Muramatsu T, Arakawa S, Fukazawa K, et al. In vivo gene electroporation in skeletal muscle with special reference to the duration of gene expression. Int $\mathrm{J}$ Mol Med 2001 Jan; 7(1):37-42.

[19]. Gothelf A, Gehl J. Gene electrotransfer to skin; review of existing literature and clinical perspectives. Curr Gene Ther 2010 Aug;10(4):287-99.

[20]. Shirley SA, Lundberg CG, Li F, et al. Controlled gene delivery can enhance therapeutic outcome for cancer immune therapy for melanoma. Curr Gene Ther 2015; 15(1):32-43.

[21]. Cupp CL, Bloom DC. Gene therapy, electroporation, and the future of wound-healing therapies. Facial Plast Surg 2002 Feb;18(1):53-7.

[22]. Ferguson M, Byrnes C, Sun L, et al. Wound healing enhancement: electroporation to address a classic problem of military medicine. World J Surg 2005;29 Suppl 1:S55-9.

[23]. Gothelf A, Gehl J. What you always needed to know about electroporation based DNA vaccines. Hum Vaccin Immunother 2012 Nov 1;8(11):1694-702.

[24]. Donate A, Heller R. Assessment of delivery parameters with the multi-electrode array for development of a DNA vaccine against Bacillus anthracis. Bioelectrochemistry 2013 Dec;94:1-6.

[25]. Heller LC, Jaroszeski MJ, Coppola D, et al. Optimization of cutaneous electrically mediated plasmid DNA delivery using novel electrode. Gene Ther 2007 Feb;14(3):275-80.

[26]. Athanasiou KA, Eswaramoorthy R, Hadidi P, et al. Self-organization and the self-assembling process in tissue engineering. Annu Rev Biomed Eng 2013;15:115-36.

[27]. Gibot L, Galbraith T, Huot J, et al. A preexisting microvascular network benefits in vivo revascularization of a microvascularized tissue-engineered skin substitute. Tissue Eng Part A 2010 Oct;16(10):3199-206.

[28]. Gibot L, Galbraith T, Huot J, et al. Development of a tridimensional microvascularized human skin substitute to study melanoma biology. Clin Exp Metastasis 2013 Jan;30(1):83-90.

[29]. Madi M, Rols MP, Gibot L. Efficient In Vitro Electropermeabilization of Reconstructed Human Dermal Tissue. J Membr Biol 2015 Mar 19.

[30]. Golzio M, Teissie J, Rols MP. Direct visualization at the single-cell level of electrically mediated gene delivery. Proc Natl Acad Sci U S A 2002 Feb 5;99(3):1292-7.
[31]. Deipolyi AR, Golberg A, Yarmush ML, et al. Irreversible electroporation: evolution of a laboratory technique in interventional oncology. Diagn Interv Radiol 2014 Mar-Apr;20(2):147-54.

[32]. Rols MP, Teissie J. Electropermeabilization of mammalian cells. Quantitative analysis of the phenomenon. Biophys J 1990 Nov;58(5):1089-98.

[33]. Saulis G, Saule R. Size of the pores created by an electric pulse: microsecond vs millisecond pulses. Biochim Biophys Acta 2012 Dec;1818(12):3032-9.

[34]. Golzio M, Teissie J, Rols MP. Cell synchronization effect on mammalian cell permeabilization and gene delivery by electric field. Biochim Biophys Acta 2002 Jun 13;1563(12):23-8.

[35]. Laurent J, Frongia C, Cazales $\mathrm{M}$, et al. Multicellular tumor spheroid models to explore cell cycle checkpoints in 3D. BMC Cancer 2013;13:73.

[36]. Zaharoff DA, Barr RC, Li CY, et al. Electromobility of plasmid DNA in tumor tissues during electric field-mediated gene delivery. Gene Ther 2002 Oct;9(19):1286-90.

[37]. Cemazar M, Sersa G, Wilson J, et al. Effective gene transfer to solid tumors using different nonviral gene delivery techniques: electroporation, liposomes, and integrin-targeted vector. Cancer Gene Ther 2002 Apr;9(4):399-406.

[38]. Mesojednik S, Pavlin D, Sersa G, et al. The effect of the histological properties of tumors on transfection efficiency of electrically assisted gene delivery to solid tumors in mice. Gene Ther 2007 Sep;14(17):1261-9.

[39]. Netti PA, Berk DA, Swartz MA, et al. Role of extracellular matrix assembly in interstitial transport in solid tumors. Cancer Res 2000 May 1;60(9):2497-503.

[40]. Andre FM, Gehl J, Sersa G, et al. Efficiency of high- and low-voltage pulse combinations for gene electrotransfer in muscle, liver, tumor, and skin. Hum Gene Ther 2008 Nov;19(11):1261-71.

[41]. Gothelf A, Eriksen J, Hojman P, et al. Duration and level of transgene expression after gene electrotransfer to skin in mice. Gene Ther $2010 \mathrm{Jul} ; 17(7): 839-45$.

[42]. Pavselj N, Preat V. DNA electrotransfer into the skin using a combination of one high- and one low-voltage pulse. J Control Release 2005 Sep 2;106(3):407-15.

[43]. Kos S, Tesic N, Kamensek U, et al. Improved Specificity of Gene Electrotransfer to Skin Using pDNA Under the Control of Collagen Tissue-Specific Promoter. J Membr Biol 2015 Oct;248(5):919-28.

[44]. Vandermeulen G, Richiardi H, Escriou V, et al. Skin-specific promoters for genetic immunisation by DNA electroporation. Vaccine 2009 Jul 9;27(32):4272-7. 